\title{
Healthcare Dependent Multiplier
}

\author{
Julia M. Puaschunder ${ }^{1,2}$ \\ ${ }^{I}$ The New School, Department of Economics, New York, NY 10003, USA, Julia.Puaschunder@newschool.edu, \\ www.juliampuaschunder.com \\ ${ }^{2}$ Columbia University, Graduate School of Arts and Sciences, Julia.Puaschunder@columbia.edu, \\ http://blogs.cuit.columbia.edu/jmp2265
}

\begin{abstract}
The currently ongoing COVID-19 crisis has challenged healthcare around the world. The call for global solutions in international healthcare pandemic outbreak monitoring and crisis risk management has reached unprecedented momentum. The novel coronavirus SARS-CoV-2 imposes the most unexpected external economic shock to modern humankind, triggering abrupt consumption and behavior pattern shifts around the world with widespread socio-economic impacts. In order to alleviate unexpected negative fallouts from the crisis, governments around the world have incepted the largest ever amount of strategic economic bailout rescue and recovery packages that particularly focus on economic and social targets. The potential focus of bailouts and recovery ranges from urban-local and national to even global and future-oriented beneficiaries, as pursued in public investments on climate stabilization in the United States Green New Deal or the European Green Deal Sustainable Finance Taxonomy. Largescale and future-oriented governmental investments are valuable macroeconomic multipliers that can benefit society as a whole in the short run and long term. Economic multipliers trickle down positively in society since governmental spending incepting projects leads to increased salaries, opportunities to support a family and employ other people in the consumption of goods and services, to name a few economic multiplying growth opportunities in the wake of governmental spending. This paper proposes the idea that multiplier effects may vary based on the causes that receive governmental funding. Evidence of country differences in multiplier effectiveness already exist. Multipliers also appear to trickle down in society with a certain time lag. Lastly, multiplier effects can also be negative if the government chooses to cut spending during austerity measures. The discussion proposes potential future hypothesis testing opportunities for investigating healthcare dependent multipliers. Given the enormous amount of governmental COVID rescue and recovery aid in the aftermath of the COVID-19 crisis and the blatant importance of health in the eye of the pandemic, the time has come to investigate if there is a certain effect of governmental spending on healthcare that influences the multiplier. In order to understand a potential multiplier effect of governmental spending on healthcare, a healthcare dependent multiplier effect could test if healthcare related governmental spending leads to a higher or lower than 1.6 multiplying factor. If a relation between multiplier effects and healthcare exists, a future step would be to investigate if it also holds or varies for particular governmental investment in prevention and preventive healthcare. If there are effects for governmental spending on healthcare, well-being and social welfare are potential moderators of the effect. In the $21^{\text {st }}$ century, healthcare is directly related to digitalization and technological advancement, which could be other moderators to control for. Lastly, corruption has been found to be negatively related to quality healthcare and may also be accounted for in future healthcare related multiplier investigations. The paper ends with an outlook on policy implications of the prospective envisioned research.
\end{abstract}

KEYWORDS: Austerity, Coronavirus, Corruption, COVID-19, Digitalization, Economic contraction, Economic growth, European Green Deal, Finance, Green New Deal, Government spending, Health, Healthcare, Multiplier, Negative multiplier, Pandemic, Positive multiplier, Prevention, Preventive care, Public policy, Recovery, Rescue and recovery aid, Social welfare, Trickle down effect, Well-being

\section{Introduction}

The novel coronavirus SARS-CoV-2 imposes the most unexpected external economic shock to modern humankind (Baldwin \& di Mauro 2021). So far over 200 million recorded infected people have caused over four million documented deaths related to the disease in over 220 countries and territories around the globe (Worldometer 2021). Early on scientific estimations accounted for about $80 \%$ of the world population to get infected with the virus in dense areas in 
one form or another at a point in their life (BBC 2020). With about 10-up to over $30 \%$ of previously infected to develop long-term impacts of the disease, we can say that COVID-19 will be the most prevailing external change factor of our current generation (Coleman 2021; Economist 2021).

In almost all major world countries, the pandemic required governments to take drastic steps to stabilize the economy since consumption, trade and finance flows changed dramatically. In the international arena, central banks of all major world economies - such as Australia, Brazil, Canada, Denmark, Japan, New Zealand, Singapore, South Korea, Sweden, Switzerland, United Kingdom, United States - and the European Central bank coordinated to lower the price of USD liquidity swap line arrangements in order to foster the provision of global liquidity (Alpert 2021). The International Monetary Fund (IMF) and the World Bank issued economic stimulus and relief efforts in the range of around 260 billion USD with the majority of relief aid being distributed in the developing world (Alpert 2021; World Bank 2020). As of May 2021, all major economies responded to the economic fallout of COVID19. In response to the ongoing COVID-19 crisis, all major economies around the world have rolled out economic-assistance packages or recovery releases that by mid-2020 already are summing up to over 10 trillion USD and with continuous prospects of renewal and further development (Cassim 2020; The White House 2020).

Across countries, economic-stimulus responses to the COVID-19 crisis outsize those to the 2008 financial crisis (Cassim, Handjiski, Schubert \& Zouaoui 2020; The White House 2020). The qualitative and quantitative stimulus, rescue and recovery aid have surpassed any other similar attempt in human history. Economic COVID-19 stimulus and relief efforts mainly comprise of international fiscal and monetary stimulus and relief efforts but also direct rescue bailout packages. The potential focus of bailouts and recovery ranges from urban-local and national to even global and future-oriented beneficiaries, as pursued in public investments on climate stabilization in the United States Green New Deal or European Green Deal Sustainable Finance Taxonomy.

The paper sheds light on the potential to use the funds to aid healthcare with particular attention to John Maynard Keynes' idea of the multiplier. This paper addresses the unprecedentedly large governmental rescue and recovery aid in light of its potential to invest in healthcare.

The traditional Keynesian approach (1936) gave rise to the concept of the government spending multiplier. During the Great Depression of the 1930s, economist John Maynard Keynes argued that 1 point change in government spending, $G$, total output, $Y$ would increase by a greater factor, estimated to be around 1.6 points. The increase in investment or government spending will raise output one-for-one, but then some of the income generated by output increase will be spent on consumption, which will generate more output and so on. The overall total output function of an economy would be $Y=C+I+G$ where $C$ and $I$ are total consumption and investment in a closed economy model. The intuition of the multiplier can be derived from accounting relationships.

The currently ongoing COVID-19 crisis has challenged healthcare around the world. The pandemic has made already long existing healthcare inequality even more blatantly transparent as ever before (Puaschunder \& Beerbaum 2020). With the Coronavirus crisis imposing the most challenging healthcare crisis of the last century and the most worldwide spread pandemic ever occurred in our contemporary society, we need a better understanding how to use governmental unprecedentedly-highest-ever rescue and recovery for health purposes and if a specific focus on preventive care and healthy long-term lifestyles impacts the economic multiplier, well-being and/or societal welfare. The discussion highlights future proposed research also in light of the United States Green New Deal and the European Green Deal. 


\section{Coronavirus crisis}

The novel coronavirus SARS-CoV-2 imposes the most unexpected external economic shock to modern humankind (Baldwin \& di Mauro 2021). So far over 200 million recorded infected people have caused over four million documented deaths related to the disease in over 220 countries and territories around the globe (Worldometer 2021). Early on scientific estimations accounted for about $80 \%$ of the world population to get infected with the virus in dense areas in one form or another at a point in their life (BBC 2020). With about 10 -up to over $30 \%$ of previously infected to develop long-term impacts of the disease, we can say that COVID-19 will be the most prevailing external change factor of our current generation (Coleman 2021; Economist 2021).

\section{Coronavirus crisis rescue and recovery aid}

In order to alleviate unexpected negative fallouts from the crisis, global governance and governments around the globe engaged in bailouts and recovery packages of extraordinary size and scope (Alpert 2021). In the international arena, central banks of all major world economies such as Australia, Brazil, Canada, Denmark, Japan, New Zealand, Singapore, South Korea, Sweden, Switzerland, United Kingdom, United States - and the European Central bank coordinated to lower the price of USD liquidity swap line arrangements in order to foster the provision of global liquidity (Alpert 2021; European Central Bank 2020; Federal Reserve Bank of the United States of America 2020). The International Monetary Fund (IMF) and the World Bank issued economic stimulus and relief efforts in the range of around 260 billion USD with most of the relief aid being distributed in the developing world (World Bank 2020).

As of May 2021, all major economies responded to the economic fallout of COVID-19. In response to the ongoing COVID-19 crisis, all major economies around the world have rolled out economic-assistance packages or recovery releases that by mid-2020 already are summing up to over 10 trillion USD and with continuous prospects of renewal and further development (Cassim et al. 2020; The White House 2021).

Across countries, economic-stimulus responses to the COVID-19 crisis outsize those to the 2008 financial crisis. The qualitative and quantitative stimulus, rescue and recovery aid have surpassed any other similar attempt in human history (Alpert 2021). Economic COVID19 stimulus and relief efforts mainly comprise of international fiscal and monetary stimulus and relief efforts but also direct rescue bailout packages (Alpert 2021). The highest-ever and most broad-based often-intergovernmentally concerted funding efforts around the world are often targeted at specific causes. For instance, the potential focus of bailouts and recovery ranges from urban-local and national to even global and future-oriented beneficiaries, as pursued in public investments on climate stabilization in the Green New Deal or European Green Deal Sustainable Finance Taxonomy.

\section{Multiplier effect}

The unprecedented size, scope and focus of large-scale governmental investments around the world are economically justified by the idea of the economic multiplier effect of governmental investments, which was first described in John Maynard Keynes' The General Theory of Employment, Interest and Money (1936). During the Great Depression of the 1930s, Keynes (1936) found that large construction projects but also innovation in research and development are valuable macroeconomic accelerators and multipliers that can benefit society as a whole in the short and long term.

The general positive multiplier effect is estimated to be around a 1.6 multiplier meaning that 1 USD spent by the government leads to an overall increase of the economy by 1.6 USD due to multiplier effects in money spent leading to consumption leading to economic 
growth. The underlying assumption is that governmental spending in investment projects create economic growth and prosperity for all parts of society due to trickle down effects.

There is also a negative multiplier, hence a contraction in case of governmental austerity measures, which can be found on the international level (Social Research 2013). If austerity is implemented, economic growth potential is restricted. During recessions, austerity policies hamper economic recovery (Social Research 2013). Semmler (2013) analyzes austerity in the European Union and shows that in periods of high financial stress and recession, the fiscal consolidation intended to stabilize debt is costly in terms of harming growth. Semmler (2013) concludes that the cure is worse than the disease and in fact contributes to it.

Governmental spending in the multiplier is unique insofar as governments and intergovernmental bodies have the long-term vision and financial freedom to operate on deficits but also the regulatory means to enact large-scale redistribution and long-term wealth creation in grand investments for the future. State-dependent multiplier studies find differences between countries (Mittnik \& Semmler 2011). Mittnik and Semmler (2011) empirically outline that the multiplier depends on the timing of the demand shock as there is a significantly higher multiplier in times of low demand than in times of high demand. This is because there are significant constraints in times of recession in the labor, product and financial markets. Multipliers appear to have a higher impact in high stress regimes, evidenced by the strong contractionary multiplier that Greece in the aftermath of the 2008/09 crisis witnessed due to constraints in the labor, product, and financial markets worsening due to austerity (Mittnik \& Semmler 2011). Not only is the multiplier stronger in bad times, but its effects are also stronger for big shocks (Mittnik \& Semmler 2011). In 2012, the International Monetary Fund (IMF) found that the state dependent multiplier triggered by austerity was strongly contractionary when enacted in a recession (Mittnik \& Semmler 2011). All these results imply the importance to consider the particular state of the economy at the time the fiscal expenditure becomes effective consistent with Keynesian theory and empirical trends of net borrowing over the business cycle (Mittnik \& Semmler 2011).

\section{Multiplier effect during the Coronavirus crisis}

In the aftermath of the COVID-19 pandemic shock and its subsequent economic fallout, the currently largest-ever governmental rescue and recovery aid is justified by the positive multiplier effect in the hope for a revitalization of the economy. In many countries, governmental crisis aid is particularly pegged to concrete social, economic and environmental causes. For instance, in the United States, the current rescue funds are targeting a transition to renewable energy in the wake of the so-called Green New Deal (GND).

Inspired by the economic success story of the New Deal reform of the United States to recover from the Great Depression of the 1920s, the so-called Green New Deal (GND) is the most advanced governmental attempt to secure a sustainable economic solution in harmony with the earth's resources (Braga, Fischermann \& Semmler 2020). The GND advocates for using a transition to renewable energy and sustainable growth in order to stimulate economic growth $\left(116^{\text {th }}\right.$ Congress of the United States, House Resolution 109, Introduced Feb 7, 2019). The post-COVID-19 recovery era is also a time of blatant disparities and inequalities in terms of access to healthcare and social justice. In times of rising inequality, the GND has also become a vehicle to determine the COVID-19 economic bailout and recover aid targets. The GND thereby combines Roosevelt's economic approach with modern ideas of economic stimulus incentivizing industries for a transition to renewable energy and resource efficiency as well as healthcare equality and social justice pledges (Puaschunder 2020, 2021).

The currently ongoing COVID-19 crisis has challenged healthcare around the world. The pandemic has made already long existing healthcare inequality even more blatantly 
transparent as ever before (Puaschunder \& Beerbaum 2020). The common call for global solutions in international healthcare pandemic outbreak monitoring and crisis risk management has reached unprecedented momentum. With the Coronavirus crisis imposing the most challenging healthcare crisis of the last century and the most worldwide spread pandemic ever occurred in our contemporary society, the largest-ever governmental rescue and recovery aid could target at boosting healthcare. COVID-19 can also be interpreted as a great reset advantage to use the potential of released funding for the improvement of healthcare provision, potentially with a focus on preventive care as prevention and a healthy diet have been proven to aid on COVID trajectories and disease outcomes (Salzburg Declaration 2020; Salzburg European Declaration 2021).

\section{Research proposal}

Future hypothesis testing opportunities could investigate the relation between governmental spending on healthcare associated with multiplier effects, which would indicate if there is a healthcare dependent multiplier effect. If a relation between multiplier effects and healthcare exists, a future step would be to investigate if it also holds or varies for particular governmental investment in prevention and if well-being and social welfare or digitalization and corruption are potential moderators of the effect.

While prevention could curb multiplier effects, especially in terms of healthy nutrition and less food intake, preventive care may boost the overall well-being and social welfare of a society. With pre-existing prevalence, such as obesity and diabetes, but also the immune system influencing the COVID disease trajectory, preventive care and whole-rounded lifestyles have gained unprecedented societal attention and demand (Ecowellness Group 2020, 2021). Creative Ecowellness options and sustainable lifestyle innovations take into account health and well-being, considering the given natural constraints set by ecological limits. The outbreak of the novel Coronavirus has sparked new community development to live in harmony with nature, which is forming in so-called agri- or agrohoods, which are neighborhoods that are directly attuned to the surrounding and celebrate the natural and cultural heritage (Agritecture 2021; Garden Destinations 2021). Moving to cheaper suburbs allows a remote workforce to build wellness cocoons, in which individuals can pay attention to healthy living embedded harmoniously in nature. The environment is also represented by biophilic architecture resembling the natural environment, which is currently booming (Pearlman 2020). The fashion world has picked up the trend in the form of sustainable fabrics (Team Linchpin 2021). Fungus clothing booms in the design world as a carbon-negative and organic alternative to fast fashion (Wolfrom 2020). In interior design of private living spaces, cleanliness and hygiene have become key factors. Aerosol sprays and air purification systems boom. Hygienic antibacterial surfaces optimized for cleanability and technologicallyenhanced kitchens came into high demand as outdoor dining plummeted and people were in a better position for home cooking instead of spending considerable amounts of time commuting and getting ready to leave the house (Dizik 2020). Attention to healthy nutrition is on the rise among Long Haulers, many of whom appear to have a craving for minimalistic stimulation at home and an anti-inflammatory diet with no glutamates, additives and preservatives infused in meals that apparently can cause problems for COVID Long Haulers (Ecowellness Group 2020, 2021). With more efficient online retail options available, and people spending more time at home during lock-downs and moving to the suburbs, minimalism has become a home trend for Long Haulers. Exhausted long-term sufferers from COVID appear to try to make sense of an even more complex world and will likely eliminate unnecessary items that clog their primary location in a search for simplicity.

Future studies may investigate if preventive healthcare related governmental support is either a positive multiplier due to general well-being enhancement, healthier life outcomes 
and societal welfare elevation. In light of the minimalism practiced, however, preventive healthcare related investment may also lead to a short-term consumption crunch.

In terms of digitalization, healthcare of tomorrow consists of Artificial Intelligence, algorithms, big data-derived inferences and robotics in healthcare (Puaschunder 2019a, b). Examining medical responses to COVID-19 on a global scale makes international differences in the approaches to combat global pandemics with technological solutions apparent. In the medical sector, individual medical information could be interpreted in the context of larger datasets in order to diagnose and predict the individual health status and likely outcomes of medical conditions. To prevent future pandemics, mobile monitoring and digital health resource tracking will play an unprecedented role. Thanks to new technologies for selfmotivated health monitoring, it is currently possible for everyone to monitor their health independently and change their lifestyle over a longer time horizon. Individualized health status apps are currently being developed to track body functions and detect virus infections in real-time. Big data that is used to obtain objective disease risk and outcome trajectory every person faces can aid in optimizing one's own lifestyle and health to prevent negative consequences early on. Currently emerging innovations such as real-time monitoring of the immune system, microchips for tracking biomarkers or large data and the use of Bluetooth technology for cartography of healthcare devices could be used to overcome bottlenecks allocation problems and combats the misuse of resources.

Empirically, the future research could investigate if investment in healthcare improves the multiplier effect and if digitalization has a moderator effect on this relationship. For instance, internet connectivity could serve as a proxy for digitalization.

When comparing countries worldwide, AI advancement is found to be positively correlated with anti-corruption (Puaschunder forthcoming). AI thus springs from non-corrupt territories of the world. Puaschunder and Beerbaum (2020) presented a novel anti-corruption artificial healthcare index that highlights those countries in the world that have vital AI growth in a non-corrupt environment. These non-corrupt AI centers hold comparative advantages to lead on global artificial healthcare solutions against COVID-19 and serve as pandemic crisis and risk management innovators of the future. Anti-corruption is also positively related with better general healthcare. Anti-corruption thus appears to be an interesting additional moderator variable to test in when investigating the healthcare dependent multiplier.

Overall, highlighting longer term outcomes and impacts in the preventive healthcare provision around the world, will determine the living conditions and peace prospects of this generation and those to come.

\section{References}

$116^{\mathrm{TH}}$ CONGRess of THE United States, House Resolution 109, Introduced Feb 7, 2019, Recognizing the duty of the Federal Government to create a Green New Deal. Accessed Sept 30, 2020 at https://www.congress.gov/116/bills/hres109/BILLS-116hres109ih.pdf.

Agritecture. 2021. The Agrihoods are coming. Jun. 17, 2021, https://www.agritecture.com/blog/2021/6/17/theagrihoods-are-coming.

Alpert, Gabe. 2021. "International COVID-19 Stimulus and Relief: International fiscal and monetary stimulus and relief efforts." INVESTOPEDIA. May 26, 2021, https:/www.investopedia.com/government-stimulus-and-reliefefforts-to-fight-the-covid-19-crisis-5113980.

Baldwin, Richard \& Beatrice Weder di Mauro (eds.). 2021. "Economics in the Time of COVID-19." CERP Press. https://cepr.org/sites/default/files/news/COVID-19.pdf.

BBC News Scotland. 2020. "50-80\% of population could be affected by coronavirus." March 2, 2020, https://www.bbc.com/news/av/uk-scotland-51711747.

Braga, João Paulo, Thomas Fischermann \& Willi Semmler. 2020. „Ökonomie und Klimapolitik: So könnte es gehen.“ Die Zeit, 11, 5, March 10, 2020.

Cassim, Ziyad, Borko Handjiski, Jörg Schubert, and Yassir Zouaoui. 2020. "The \$10 trillion rescue: How governments can deliver impact Governments have announced the provision of trillions of dollars in crisis 
relief, but translating that into sustained recovery will not be easy." McKinsey, Public Sector Practice report, June 2020. https://www.mckinsey.com/ /media/McKinsey/Industries/Public\%20Sector /Our\%20Insights/The $\% 2010 \% 20$ trillion $\% 20$ dollar\%20rescue $\% 20 H o w \% 20$ governments $\% 20$ can $\% 20$ deliver $\%$ 20impact/The-10-trillion-dollar-rescue-How-governments-can-deliver-impact-vF.pdf

Coleman, Justine. 2021. "CDC study on COVID-19 long-haulers: Two-thirds of non-hospitalized patients receive new diagnoses." The Hill, Apr. 23, 2021. https://thehill.com/policy/healthcare/549950-cdc-study-on-covid-19-longhaulers-two-thirds-of-non-hospitalized-patients.

Dizik, Alina. 2020. "Top Interior Design Trends of 2020: From Home Offices to Two-Tone Kitchens Homeowners stuck inside because of Covid-19 are analyzing every detail, from fixtures and color schemes to how each room is utilized." The Wall Street Journal, Aug. 16, 2020, https://www.wsj.com/articles/top-interior-design-trends2020-11597342299.

EcoWellness Group. 2021. "Salzburg European Declaration from the Gasteinertal: Interdisciplinary Conference on 'System change?! The chance of transformation of the healthcare system." July 14-15, 2021, https://www.oekowellness.de/wp-content/uploads/2021/07/Final-Stand-5.7.-2021.07.04_Programm-14.7.-und15.07.2021-2.pdf (last visited August 23, 2021).

European Central Bank. 2020. Coordinated central bank action to enhance the provision of global US dollar liquidity (Mar. 15, 2020), https://www.ecb.europa.eu/press/pr/date/2020/html/ecb.pr200315 1fab6a9flf.sv.html.

Federal Reserve of the United States of America. 2020. Federal Reserve announces the establishment of temporary U.S. dollar liquidity arrangements with other central banks, Mar. 19, 2020, https://www.federalreserve.gov/newsevents/pressreleases/monetary20200319b.htm.

Garden Destinations. 2021. Agrihoods: A new trend in lifestyle living. Accessed September 7, 2021, https://www.gardendestinations.com/agrihoods-a-new-trend-in-lifestyle-living/.

Keynes, John Maynard. 1936. The general theory of employment, interest and money. London: Macmillan.

Pearlman, Alex. 2020. Biophilic homes prove nature is the best medicine: Living design elements create a serene, multisensory, healing experience. Accessed September 7, 2021, https://neo.life/2020/12/biophilic-homesprove-nature-is-the-best-medicine/.

Puaschunder, Julia Margarete. 2019a. Artificial Intelligence, Big Data, and Algorithms in Healthcare, Report on behalf of the European Parliament European Liberal Forum in cooperation with The New Austria and Liberal Forum, 2019. Retrieved at https://papers.ssrn.com/sol3/papers.cfm?abstract_id=3472885

Puaschunder, Julia Margarete. 2019b. Artificial Intelligence Market Disruption. Proceedings of the International RAIS Conference on Social Sciences and Humanities organized by Research Association for Interdisciplinary Studies at Johns Hopkins University, Montgomery County Campus, Rockville, MD, United States, June 10-11, (2019b): 1-8.

Puaschunder, Julia Margarete. 2020. "The Green New Deal: Historical foundations, economic fundamentals and implementation strategies." Proceedings of the $18^{\text {th }}$ Research Association for Interdisciplinary Studies Conference on Social Sciences and Humanities, August 17, 2020.

Puaschunder, Julia Margarete. 2021. "Monitoring and Evaluation (M\&E) of the Green New Deal (GND) and European Green Deal (EGD)." $21^{\text {st }}$ Research Association for Interdisciplinary Studies (RAIS) Conference Proceedings, pp. 202-206, March 1, 2021.

Puaschunder, Julia Margarete. forthcoming. The future of Artificial Intelligence in international healthcare: An index. Vienna, Austria: Austrian Academy of Sciences.

Puaschunder, Julia Margarete. \& Dirk Beerbaum. 2020. "Healthcare inequality in the digital $21^{\text {st }}$ century: The case for a mandate for equal access to quality medicine for all." Proceedings of the 1st Unequal World Conference, United Nations New York, New York, United States.

Semmler, Willi. 2013. "The Macroeconomics of Austerity in the European Union." In: Social Research: An International Quarterly, Special issue on Austerity: Failed economics but persistent policy, 80, 3, The New School for Social Research

Social Research: An International Quarterly. 2013. Special issue on Austerity: Failed economics but persistent policy, 80,3 , The New School for Social Research.

Team Linchpin. 2021. Trends Transforming the Sustainable Clothing Industry Outlook In 2021 (Jun. 17, 2021), https://linchpinseo.com/trends-in-the-sustainable-clothing-industry/.

Tomek, Reinhardt Stefan et al. 2020. Salzburg Declaration, Outcome of the Conference on "System Change?! The Chance of Transformation of the Healthcare Sector: Analysis and Chance Within the Coronavirus Crisis." Sept. 2020, https://europepmc.org/article/ppr/ppr242581, 2020.

The Economist. 2021. "Post-COVID syndrome researchers are closing in on long covid: The results are alarming." ECONOMIST, Apr. 29, 2021. https://www.economist.com/special-report/2020/10/08/changing-places, https://www.economist.com/science-and-technology/2021/04/29/researchers-are-closing-in-on-long-covid

The IMF's Response to COVID-19, INT'L MONETARY Fund, Accessed May 13, 2020, https://www.imf.org/en/About/FAQ/imf-response-to-covid-19. 
The White House. 2020. “Briefing Room, President Biden Announces American Rescue Plan.” January 20, 2021. THE WHITE HOUSE, https:/www.whitehouse.gov/briefing-room/legislation/2021/01/20/president-biden-announcesamerican-rescue-plan/

Wolfrom, Jessica. 2020. "When Fashion is Fungal." WASHINGTON Post, Aug. 31, 2020. https://www.washingtonpost.com/climate-solutions/2020/08/31/fashion-musrhooms-mycelium-climate/.

World Bank, Press Release. 2020a. "World Bank Group: 100 Countries Get Support in Response to COVID-19 (Coronavirus)." WORLD BANK, Accessed Sept. 7, 2020, https://www.worldbank.org/en/news/pressrelease/2020/05/19/world-bank-group-100-countries-get-support-in-response-to-covid-19-

coronavirus\#: :text=WASHINGTON\%2C\%20May\%2019\%2C\%202020\%E2\%80\%94,70\%25\%20of $\% 20$ the \%20world $\% 27 \mathrm{~s} \% 20$ population.\&text $=$ Of $\% 20$ the $\% 20100 \% 20$ countries $\% 2 \mathrm{C} \% 2039 \% 20 \mathrm{are} \% 20 \mathrm{in} \% 20 \mathrm{Sub} \% 2$ DSaharan \%20Africa.

World Bank, Press Release. 2020b. "World Bank Group Announces Up to \$12 Billion Immediate Support for COVID-19 Country Response." WORLD BANK, Accessed March 16, 2020, https://www.worldbank.org/en/news/press-release/2020/03/03/world-bank-group-announces-up-to-12-billionimmediate-support-for-covid-19-country-

response\#: :text=WASHINGTON\%2C\%20March\%203\%2C\%202020\%20\%E2\%80\%94,impacts\%20of\%20 the $\% 20$ global\%20outbreak.

World Bank, Press Release. 2020c. "World Bank Group Increases COVID-19 Response to \$14 Billion To Help Sustain Economies, Protect Jobs." Accessed March 17, 2020, https://www.worldbank.org/en/news/pressrelease/2020/03/17/world-bank-group-increases-covid-19-response-to-14-billion-to-help-sustain-economiesprotect-jobs.

Worldometer. 2021. Coronavirus Live Update, https://www.worldometers.info/coronavirus/. 